\title{
Assessment of bio-accumulation of bacteria in oysters from shellfish growing waters in Ashtamudi Lake (Kerala, India): A RAMSAR wetland
}

\author{
S. Chinnadurai *, K.S. Mohamed, J. Sharma, V. Venkatesan, V. Kripa \\ Molluscan Fisheries Division, ICAR-Central Marine Fisheries Research Institute, PB No: 1603, Kochi-682018, Kerala, India
}

\section{H I G H L I G H T S}

- In India, this is the first-ever assessment, which offer an insight on the accumulation of bacteria in farmed oysters.

- We investigated the dynamic process of microbial bio-accumulation and how it is influenced by rainfall.

- Bio-accumulation was high during the pre-monsoon season when the Lake is brackish.

- Salinity and temperature play a major role in the survival of coliform bacteria in the shellfish growing water.

- We can reduce input costs in the laboratory by analysing faecal coliform as a quality indicator instead of using $E$. coli as an indicator.

\section{A R T I C L E I N F O}

\section{Article history:}

Received 20 January 2016

Received in revised form

20 May 2016

Accepted 31 May 2016

Available online 4 June 2016

\section{Keywords:}

Ashtamudi Lake

Bio-accumulation

Bivalve fishing

Crassostrea madrasensis

E. coli

\begin{abstract}
A B S T R A C T
Oysters are commercially cultured from the Ashtamudi Lake in India, and support 12,000 tonnes of bivalve fisheries/year. Oysters and oyster growing waters were sampled from July 2012 to June 2013 for analysis of total coliforms (TC), faecal coliforms (FC), Escherichia coli, faecal Streptococci (FS) and total plate counts (TPC). E. coli MPN values in oyster growing waters were below the threshold limits set by the USFDA and EU during the months of December to April. Seasonally, the highest MPN values for $E$. coli were obtained during the monsoon season (June-September), and this trend gradually decreased during the post-monsoon (October-January) and pre-monsoon (February-May) periods. E. coli displayed a significant $(p<0.01)$ variation in accumulation during different seasons. A strong negative correlation $\left(R^{2}=-0.70, p<0.05\right)$ between temperature and $E$. coli numbers in oysters was observed, while rainfall and $E$. coli were positively correlated $\left(R^{2}=0.695, p<0.05\right)$. Hence, we strongly recommend depuration and proper cooking of oysters before consumption during the monsoon season.
\end{abstract}

(c) 2016 Elsevier B.V. All rights reserved.

\section{Introduction}

Coastal estuaries are highly productive ecosystems that can sustain several human activities. These aquatic environments are among the most extensively used for the commercial production of bivalves (Almeida and Soares, 2012). The microbiological pollution of coastal waters is a major problem, especially in shellfish growing areas where contamination may exist, with sewage discharges including sewage outfall, combined sewer overflows and rainwater discharges the most significant (Lee et al., 2003; Oliveira et al., 2011). As filter feeding organisms, bivalves can concentrate contaminants from the surrounding water including microorganisms that can cause several infectious diseases in humans (Muniain-Mujika et al., 2002; Brands et al., 2005).

\footnotetext{
* Correspondence to: Fishing Technology Division, ICAR-Central Institute of Fisheries Technology, Kochi-682029, Kerala, India.

E-mail address: chinnaduraitvl@gmail.com (S. Chinnadurai).
}

Consumption of shellfish containing harmful microorganisms may pose a significant public health risk (Fleming et al., 2006); thus, their hygiene and sanitary control is extremely important and is legislated in many countries (Lees, 2000; Oliveira et al., 2011). Classification of growing areas by sanitary survey and monitoring of $E$. coli/faecal coliforms at an appropriate frequency based on the risk of contamination is prevalent in Europe. These classifications are based on Directives 923/79/CEE, which serve as guidelines to control the levels of microorganisms in both shellfish and the overlying waters (EC, 2004a). These standard guidelines are important for the regulation of shellfish harvesting and public health. In India, such standards have not yet been developed because until recently there was no significant consumption of shellfish. However, shellfish cultivation has substantially increased in recent decades and has become an important industry for rural coastal communities. Indigenous species of clams, mussels and oysters are harvested from natural populations, and the characteristics of these bivalve molluscs make them suitable for 
cultivation. In India, the cultivation of the oyster Crassostrea madrasensis is performed mainly in the estuaries and backwaters of Kerala, particularly from Ashtamudi Lake. The production of the oyster $C$. madrasensis was nil in the year 1990 and reached 4700 tonnes in 2013 (FAO, 2013). Recently, the edible oysters are very popular as raw and processed food in the South Indian states, particularly in Kerala and Goa (Jana et al., 2013), where large number of foreigners visiting every year. The trade of live oysters also has a high demand in high-end restaurants, and their market value has increased tremendously from Rs 0.5/oyster to 7.5/depurated oyster (Mohamed and Kripa, 2013). Under these circumstances, the shellfish harvesting areas in India have to be classified as suitable to harvest for direct human consumption based on purification by depuration/relaying or approved processing. Perusal of availability of informations reveals that few work have been done on the aspect of bioaccumulation in green mussels in recent years (Raveendran et al., 1990; Sasikumar and Krishnamoorthy, 2010). Both the authors found that, bioaccumulation of faecal coliforms were high during monsoon and well below the threshold limit in pre-monsoon and post-monsoon seasons. But none of the work has been done on oyster. Therefore, it is important to document how varying bacterial community in different season's oysters and overlying waters. The aims of the current study was to monitoring the seasonal variation of bioaccumulation of bacterial load in the edible oyster and suggest harvest and post-harvest management practices for oyster farmers. Based on this background, we studied the bio-accumulation of bacteria (Faecal coliforms, E. coli, faecal Streptococci and Total plate count) in oysters $C$. madrasensis and growing waters of the shellfish in Ashtamudi Lake from July 2012 to June 2013.

\section{Materials and methods}

\subsection{Study area}

Ashtamudi Lake is the second largest brackish water lake in Kerala (Lat. $8^{\circ} 56^{\prime} 46.18^{\prime \prime} \mathrm{N}$ and Long. $76^{\circ} 33^{\prime} 16.33^{\prime \prime} \mathrm{E}$ ) and has been designated as a Ramsar site based on the Ramsar Convention of Wetlands in 2002. The lake has an area of $61.4 \mathrm{~km}^{2}$ and supports approximately 12,000 tonnes of bivalve fisheries per year. Oysters are an important edible bivalve mollusc commercially exploited from this lake. The lake is permanently connected with the Arabian Sea, and the water is exchanged daily by tides. The Kallada River flows into the lake and makes the lake brackish, which is favourable for bivalve growth. The lake is classified as mesotrophic with optimum nutrient concentration levels and good water exchange. For many bivalve species it is an important spawning and nursery ground (especially for clams) due to its sheltered condition. The bivalve fisheries and mariculture activities in this area are economically important.

\subsection{Sample collection}

Monthly collection of oysters (C. madrasensis) and harvesting waters were performed from July 2012 to June 2013. During each sampling 30 oysters and water (50 $\mathrm{cm}$ below the surface) from the harvesting area were collected from the commercial bivalve fishing areas of the lake. Water was collected at the surface using $500 \mathrm{ml}$ sterile bottles. Water physico-chemical parameters (i.e., temperature, salinity and $\mathrm{pH}$ ) were measured separately. The oyster and water samples were transported to the laboratory in an insulated ice-box under aseptic conditions within $4 \mathrm{~h}$. The analyses were performed on the same sampling day.

\subsection{Bacterial analyses}

Upon arrival at the laboratory, the oysters were cleaned by scrubbing and washing under running water and drained with clean sterilized cotton. Next, the oysters were shucked with a sterile knife and the flesh and intervalvular fluid were extracted aseptically. Accumulation factors were calculated based on the method described by Burkhardt et al. (1992), where the, Bioaccumulation Factor (BAF), BAF $=\mathrm{Co} / \mathrm{Cw}$. Where, $\mathrm{Co}=$ the faecal coliforms concentration in oysters and $\mathrm{CW}=$ the faecal coliforms concentration in waters. The bio-accumulation of faecal coliforms from the shellfish raising water of the backwater oyster was investigated from July 2012 to June 2013. Each bacterial analysis was performed in triplicate.

\subsection{Faecal coliforms and E. coli}

The concentrations of faecal coliforms (FC) and E.coli were enumerated using the multi-fermentation method (most probable number-MPN) in accordance with the American Public Health Association method (APHA, 2012). Decimal dilutions of the samples were inoculated into Lauryl Tryptose Broth (HiMedia, Mumbai, India) at $37{ }^{\circ} \mathrm{C}$ for $48 \mathrm{~h}$ using five tubes per dilution. All LTB tubes that showed turbidity and gas production were selected and $1 \mathrm{ml}$ were transferred to tubes containing $2 \%$ Brilliant Green Lactose Broth (HiMedia, Mumbai, India) and E. coli broth (HiMedia, Mumbai, India). Tubes with BGLB were incubated at $35{ }^{\circ} \mathrm{C}$ for $48 \mathrm{~h}$ and tubes with EC were incubated in a water bath at $45.5{ }^{\circ} \mathrm{C}$ for $48 \mathrm{~h}$. BGLB tubes with turbidity and gas production were quantified, and the most probable number (MPN) of coliforms per gram was determined using the MPN table for three tubes. The cultures in EC broth showing turbidity and gas production were streaked on eosin-methylene blue agar (EMB), and incubated at $35{ }^{\circ} \mathrm{C}$ for $24 \mathrm{~h}$. Typical $E$. coli colonies were submitted indole, methyl red, Voges Proskauer and citrate (IMViC) biochemical tests. Faecal coliform and E. coli densities were estimated by computing the MPN index corresponding to the positive tube combinations. The results were expressed as MPN $100 \mathrm{ml}^{-1}$ of water and MPN $100 \mathrm{~g}^{-1}$ of shellfish.

\subsection{Total plate count and faecal Streptococci}

Total plate counts (TPC) were performed using the spread plating method. Decimal dilutions of samples of homogenates were inoculated in plate count agar (HiMedia, Mumbai, India) containing $3 \% \mathrm{NaCl}$ and examined for colony development after incubation for $48 \mathrm{~h}$ at $36 \pm 1{ }^{\circ} \mathrm{C}$. Colonies were counted and the data reported as colony forming units per gram (cfu/g) (Sengor, 2004; Obodai et al., 2010). Faecal Streptococci (FS) were counted on $\mathrm{KF}$ Streptococcus agar. The plates were incubated at $36 \pm 1{ }^{\circ} \mathrm{C}$ for $48 \mathrm{~h}$; dark red colonies and colonies with red and pink centres were counted as faecal Streptococci colonies. The results were expressed as the number of colony forming units per $\mathrm{ml}$ or $\mathrm{g}$ (Easterbook and West, 1987).

\subsection{Statistical analysis}

The data were expressed by seasons including Monsoon (June-Sep), Pre-monsoon (Oct-Jan) and Post-monsoon (Feb-May). All mean MPN values for TC, FC, E. coli, TPC (cfu/g), and FS (cfu/g) were converted to $\log _{10}$ values prior to analysis. Statistical analyses of shellfish bio-accumulation were conducted using SAS version 9.2. Analysis of variance (ANOVA) and Pearson correlation analyses were applied to determine the relationship between microbial bio-accumulation with various seasons and environmental parameters. 
Table 1

Seasonal variation in physico-chemical parameters of shellfish harvesting waters of Ashtamudi Lake, Kollam, Kerala. SD indicates standard deviation from the mean.

\begin{tabular}{|c|c|c|c|c|c|}
\hline Season & & Temperature $\left({ }^{\circ} \mathrm{C}\right)$ & Salinity (psu) & $\mathrm{pH}$ & Rainfall (mm) \\
\hline \multirow{4}{*}{ Monsoon } & Mean & 28.05 & 20.02 & 7.9 & 554.5 \\
\hline & SD & 0.98 & 8.52 & 0.26 & 236.8 \\
\hline & Min & 26.60 & 13.0 & 7.7 & 366.5 \\
\hline & Max & 28.80 & 32.0 & 8.3 & 887.0 \\
\hline \multirow[t]{4}{*}{ Post-monsoon } & Mean & 29.49 & 30.5 & 8.1 & 192.2 \\
\hline & SD & 0.23 & 2.27 & 0.15 & 163.7 \\
\hline & Min & 29.1 & 27.5 & 8.0 & 0.0 \\
\hline & Max & 29.6 & 33.0 & 8.3 & 371.0 \\
\hline \multirow[t]{4}{*}{ Pre-monsoon } & Mean & 29.85 & 28.42 & 8.02 & 156.0 \\
\hline & SD & 1.38 & 6.17 & 0.09 & 167.0 \\
\hline & Min & 28.3 & 22.5 & 7.9 & 19.0 \\
\hline & Max & 31.4 & 33.5 & 8.1 & 391.0 \\
\hline
\end{tabular}

Table 2

Seasonal changes in bio-accumulation factors (BAF) in C. madrasensis oysters.

\begin{tabular}{lcclr}
\hline Month & BAF & & & \\
\cline { 2 - 5 } & FC & E. coli & FS & TPC \\
\hline July & 1.45 & 2.18 & 6.25 & 1.36 \\
August & 3.79 & 2.84 & 9.5 & 1.34 \\
September & 3.79 & 5.84 & 3.0 & 2.61 \\
October & 6.66 & 1.90 & 1.0 & 9.10 \\
November & 1.50 & 1.44 & 0.93 & 1.22 \\
December & 5.86 & 4.41 & 7.0 & 24.78 \\
January & 2.60 & 7.85 & 1.75 & 4.28 \\
February & 68.35 & 17.72 & 1.30 & 2.37 \\
March & 10.0 & 5.35 & 2.50 & 2.66 \\
April & 9.89 & 9.72 & 4.25 & 5.17 \\
May & 6.66 & 1.0 & 3.75 & 2.50 \\
June & 7.50 & 2.25 & 3.16 & 12.86 \\
\hline
\end{tabular}

\section{Results}

\subsection{Environmental parameters}

The physico-chemical parameters in the shellfish growing waters of Ashtamudi Lake are shown in Table 1. Salinities fluctuated between 13 and 34 psu (mean = $26.31 \mathrm{psu}$ ), which is characteristic of a tropical estuary. The temperature fluctuated between 26.6 and $31.4^{\circ} \mathrm{C}$, conforming to typical tropical conditions. The $\mathrm{pH}$ of the lake water remained relatively constant (7.7-8.3). Variations in the environmental parameters were mostly influenced by tidal amplitude and monsoon rainfall. The highest temperature in the oyster harvesting water was recorded in the months of March-April (Pre-monsoon) and the lowest was recorded in June (Monsoon). Salinity also peaked in March-April (Pre-monsoon) and was lowest in July due to seasonal rains.

\subsection{Bio-accumulation factors}

Faecal coliforms and $E$. coli were concentrated by the shellfish to varying degrees over the 12 -month period (Table 2 ). There was a seasonal influence on the rates of accumulation of these indicators. The mean accumulation factors for faecal coliforms and E. coli in oysters during the study period was 10.67 (range, 1.45-68.35) and 5.20 (range, 1.0-17.72), respectively. The maximum accumulation for both organisms occurred during February when the water salinity (22.5 psu) and temperature $\left(29.1{ }^{\circ} \mathrm{C}\right)$ exhibited typical brackish water conditions. Thus, February was observed as a period of hyperaccumulation. The rate of bio-accumulation of $E$. coli was significantly correlated $(p<0.01)$ with the faecal coliform content of the water. In contrast, no correlation was observed between water temperature, salinity, $\mathrm{pH}$, rainfall and accumulation of faecal coliforms and E. coli.

\subsection{Coliform levels in seawater}

Mean concentrations of faecal coliforms and $E$. coli in the shellfish growing waters of Ashtamudi Lake are presented in Table 3. Throughout the study period the mean $\log 10$ MPN counts of coliforms were $3.06 \pm 0.44$ for FC and $2.82 \pm 0.47$ for $E$. coli $/ 100 \mathrm{ml}$. The occurrences of maximum FC and E. coli (3.38 MPN/100 ml) were recorded during the monsoon season, while the lowest occurrences were detected during the postmonsoon and pre-monsoon seasons. Seasonal changes in TC, FC and E. coli densities are depicted in Table 3. Pearson correlation coefficient matrices were calculated for FC and E. coli in shellfish harvesting waters with environmental parameters. Statistical analyses revealed a strong negative relationship between $E$. coli and temperature $\left(R^{2}=-0.79, p<0.01\right)$. Similarly, temperature and faecal coliform counts displayed a significant negative correlation $\left(R^{2}=-0.64, p<0.05\right)$. E. coli and TPC positively correlated with rainfall $\left(R^{2}=0.624, p<0.05\right.$ and $R^{2}=$ $0.636, p<0.05$, respectively). Correlations were not significant $(p>0.05)$ between salinity, $\mathrm{pH}$ and all coliforms.

\subsection{Coliform levels in oysters}

The densities varied between 4.25-3.14 $\log 10 \mathrm{MPN} / 100 \mathrm{~g}$ for FC and 3.73-2.87 $\log 10 \mathrm{MPN} / 100 \mathrm{~g}$ for E. coli (Table 3). The maximum FC and $E$. coli densities were recorded during the monsoon season $(3.99 \pm 0.33$ and $3.68 \pm 0.09 \log 10 \mathrm{MPN} / 100 \mathrm{~g}$, respectively), while the lowest were detected in the pre-monsoon season ( $3.8 \pm 0.4$ and $3.3 \pm 0.35 \log 10 \mathrm{MPN} / 100 \mathrm{~g}$, respectively). Seasonal changes in TC, FC and E. coli densities are illustrated in Table 3. ANOVA showed that seasonal variations in FC in oysters were significantly different $(p<0.01)$. Similarly, E. coli displayed significant variations $(p<$ 0.01 ) in accumulation during different seasons (Table 4). Pearson's correlation revealed a strong negative correlation $\left(R^{2}=-0.70\right.$, $p<0.05$ ) between temperature and $E$. coli numbers, while rainfall and $E$. coli in oyster tissues were positively correlated $\left(R^{2}=0.695\right.$, $p<0.05$ ). Correlations between salinity, $\mathrm{pH}$ and faecal coliforms were not significant $(p>0.05)$.

\subsection{Faecal Streptococci}

FS were present in all seasons both in oysters and the water. The maximum count in oysters was $1.75 \log 10 \mathrm{cfu} / \mathrm{g}$ and was observed during the monsoon season (Table 3). In contrast, a lower maximum count $(1.65 \log 10 \mathrm{cfu} / \mathrm{ml})$ was recorded in shellfish growing waters during the pre-monsoon season. While the quantity of faecal Streptococci was lower in water, bioaccumulation of faecal Streptococci in oysters was observed. The bio-accumulation factor ranged between 0.93 and 9.5 (mean, 3.69). Seasonal variations in the bio-accumulation of FS were not 
Table 3

Microbial quality of waters and oysters from the commercial shellfish harvesting areas in Ashtamudi Lake, Kollam, Kerala from July 2012 to June 2013.

\begin{tabular}{|c|c|c|c|c|c|c|c|c|c|}
\hline \multirow[t]{2}{*}{ Season } & & \multicolumn{2}{|c|}{$\begin{array}{l}\text { Faecal coliforms } \\
\left(\log _{10} \mathrm{MPN}\right) \\
100 \mathrm{ml}^{-1} 100 \mathrm{~g}^{-1}\end{array}$} & \multicolumn{2}{|c|}{$\begin{array}{l}\text { E. Coli } \\
\left(\log _{10} \mathrm{MPN}\right) \\
100 \mathrm{ml}^{-1} 100 \mathrm{~g}^{-1}\end{array}$} & \multicolumn{2}{|c|}{$\begin{array}{l}\text { Faecal Streptococci } \\
\left(\log _{10} \mathrm{cfu}\right) \\
100 \mathrm{ml}^{-1} 100 \mathrm{~g}^{-1}\end{array}$} & \multicolumn{2}{|c|}{$\begin{array}{l}\text { TPC } \\
\left(\log _{10} \mathrm{cfu}\right) \\
100 \mathrm{ml}^{-1} 100 \mathrm{~g}^{-1}\end{array}$} \\
\hline & & Water & Tissue & Water & Tissue & Water & Tissue & Water & Tissue \\
\hline \multirow[t]{4}{*}{ Monsoon } & Mean & 3.38 & 3.99 & 3.2 & 3.68 & 1.29 & 0.85 & 3.6 & 4.05 \\
\hline & SD & 0 & 0.33 & 0.17 & 0.09 & 0.06 & 0.62 & 0.07 & 0.45 \\
\hline & Min & 3.38 & 3.54 & 2.96 & 3.54 & 1.25 & 0.3 & 3.5 & 3.77 \\
\hline & Max & 3.38 & 4.25 & 3.38 & 3.73 & 1.39 & 1.75 & 3.67 & 4.72 \\
\hline \multirow[t]{4}{*}{ Post-monsoon } & Mean & 3.06 & 3.8 & 2.59 & 3.3 & 0.9 & 0.91 & 3.21 & 3.98 \\
\hline & SD & 0.21 & 0.4 & 0.34 & 0.35 & 0.55 & 0.36 & 0.24 & 0.35 \\
\hline & Min & 2.96 & 3.14 & 2.14 & 2.87 & 0.3 & 0.6 & 2.97 & 3.64 \\
\hline & Max & 3.38 & 4.2 & 2.96 & 3.73 & 1.54 & 1.3 & 3.55 & 4.36 \\
\hline \multirow[t]{4}{*}{ Pre-monsoon } & Mean & 2.74 & 3.9 & 2.69 & 3.54 & 1.24 & 0.87 & 3.1 & 3.58 \\
\hline & SD & 0.62 & 0.22 & 0.63 & 0.14 & 0.04 & 0.54 & 0.47 & 0.45 \\
\hline & Min & 1.89 & 3.73 & 1.89 & 3.38 & 0.69 & 0.3 & 2.65 & 3.07 \\
\hline & Max & 3.38 & 4.25 & 3.38 & 3.73 & 1.65 & 1.53 & 3.76 & 4.16 \\
\hline
\end{tabular}

Table 4

ANOVA comparisons of distribution of FC, E. coli, faecal Streptococci and TPC in shellfish growing waters and oysters.

\begin{tabular}{lllcl}
\hline Parameters & $R$-square & Mean square & $F$-value & $P$ value \\
\hline Faecal coliforms & 0.55 & 4.00 & 27.46 & 0.0001 \\
E. coli & 0.45 & 2.79 & 18.72 & 0.0003 \\
Faecal Streptococci & 0.08 & 0.42 & 2.17 & 0.1547 \\
TPC & 0.34 & 1.90 & 11.84 & 0.0023 \\
\hline
\end{tabular}

significant ( $p>0.05)$, but ANOVA showed significant $(p<$ 0.05 ) differences in the bio-accumulation of FS with temperature and salinity (Table 4). Pearson's correlation showed that the relationship between temperature and FS accumulation was strongly negatively correlated $\left(R^{2}=-0.698, p>0.05\right)$. The other environmental parameters did not show significant correlations.

\subsection{Total plate count}

The mean log values of TPC in oyster and shellfish growing waters of Ashtamudi Lake in different season are shown in Table 3. The TPC of oysters ranged from 3.07 to $4.72 \log 10 \mathrm{cfu} / \mathrm{g}$. The maximum mean count was observed during the monsoon season $(4.05 \pm 0.45 \log 10 \mathrm{cfu} / \mathrm{g})$ and the lowest during the premonsoon season $(3.58 \pm 0.45 \log 10 \mathrm{cfu} / \mathrm{g})$. The bio-accumulation factors ranged between 1.34 and 24.68 , with the maximum bioaccumulation factor observed in the month of December. ANOVA showed significant $(p<0.01)$ differences between TPC count in oysters and environmental parameters salinity and temperature (Table 4). Pearson's correlation coefficients revealed significant negative relationships between bio-accumulation of TPC and temperature $\left(R^{2}=-0.713, p>0.01\right)$ and salinity $\left(R^{2}=-0.631\right.$, $p>0.05)$. The other environmental parameters did not show significant correlations.

\section{Discussion}

Understanding the dynamic process of microbial bioaccumulation is of great importance in restricting bivalve harvests and ensuring consumer safety. The accumulation of faecal coliforms and $E$. coli by shellfish varied greatly between seasons. Bioaccumulation was high during the pre-monsoon season characterized by the transition from the cooler post-monsoon months to the warmer summer months. During the post-monsoon season, the levels of E.coli counts in seawater were very low, these counts extended into the pre-monsoon season. However, E. coli levels in oysters were above the EU and NSSP standard limits during the monsoon months. It has been reported that shellfish accumulate coliforms from the shellfish growing waters and then maintain these levels for long periods (Sasikumar and Krishnamoorthy, 2010). The levels of $E$. coli counts started to rise during the late pre-monsoon months and peaked during the monsoon months. The monsoon rains bring a heavy load of waters containing coliforms (mostly of faecal origin) into the lake ecosystem. Thus, this influx could result in the high FC and E. coli counts observed during the monsoon period.

Seawater temperature was significantly negatively correlated with faecal coliform and $E$. coli levels in both oyster tissues and oyster growing waters. This indicates that faecal coliforms and E. coli levels are elevated during the monsoon months (low temperatures) and less prevalent during the pre- and postmonsoon months (high temperatures). Chandran and Hatha (2003) reported that sunlight is one of the most important inactivating factors for the survival of $E$. coli in estuarine waters, and this may be the reason for lower FC and E. coli levels during the nonmonsoon months. Similarly, the accumulation of FS and TPC were also negatively correlated with temperature. Bio-accumulation of faecal coliforms and $E$. coli in oysters was more prevalent in the colder months compared to the warmer months, suggesting that at lower temperatures the bivalve molluscs could concentrate relatively more FC and E. coli in their bodies. Similar conclusions were reached by Kucuksezgin et al. (2010), who found more faecal coliforms in clams during the colder winter-spring period in Izmir Bay, Turkey.

The negative correlation between TPC and salinity supports the observation of high levels of TPC during the monsoon season. This may be due to river run-off carrying faecal waste to the lake environment. Similar observations were made for coliforms in mussels from the Netravathi-Gurpur estuary in Mangalore on the west coast of India (Sasikumar and Krishnamoorthy, 2010). Ashiq et al. (2012), reported that the Kallada River (which is the main river joining the Ashtamudi Lake) showed high levels of FC, E. coli, FS and TPC counts at the station where the Kallada River joins to the lake. Studies (Chandran and Hatha, 2003) from tropical and subtropical waters (Anderson et al., 2005) showed that coliform counts were high in areas with high influxes of freshwater. The freshwater input positively influenced the salinity and survival of coliforms (Raveendran et al., 1990; Anderson et al., 2005). These findings support our conclusion that the survival of bacteria in estuarine waters is controlled by temperature and salinity.

A strong positive correlation between E. coli and FC was observed throughout the year in oyster tissues. Therefore, monitoring of FC may better reflect seasonal accumulation activities because these organisms are concentrated to a much greater extent than $E$. coli. Similar results were found in the temperate oyster Crassostrea virginica by Hood et al. (1983), where the correlation between numbers of FC and E. coli was also strong. 
Therefore, we suggest the use of FC as a reliable shellfish quality indicator rather than $E$. coli. The main advantage of the use of FC as an indicator is that it will reduce analysis time and input costs in the laboratory.

The oysters harvested from Ashtamudi Lake had high $E$. coli levels that were well above the EU limit (230MPN/100 g) throughout the year, thus confirming it as a ' $\mathrm{B}$ ' category harvesting area according to EU standards. This requires depuration or relaying to an ' $A$ ' category area over a period of time to meet health standards prior to human consumption according to current EU regulations (EC, 2004a). This is in agreement with many of the previous studies from India (Raveendran et al., 1990; Lalitha and Surendran, 2004; Sasikumar and Krishnamoorthy, 2010; Hassan et al., 2013). Recent study by Chinnadurai et al. (2014) showed that Indian back water oysters accumulated bacterial loads above the threshold limits during the winter monsoon and they demonstrated the depuration of oysters to reduce FC and E.coli to safe levels can be accomplished within $24 \mathrm{~h}$.

Similarly, shellfish such as clams harvested from Vembanad Lake (Kerala) north of Ashtamudi Lake are reported to have high levels of faecal coliforms and E. coli (Lalitha and Surendran, 2004; Hassan et al., 2013). This may be because these two lakes are situated close to the major cities of Kerala and are interconnected with the canals of the cities that discharge sewage into the lakes. The TPC numbers recommended for good quality bivalve molluscs is 500,000/g (EC, 2004b). The TPC in oysters from Ashtamudi Lake was found to be below this threshold limit. The high levels of FC and E. coli in oysters do not pose a grave threat to consumers because the oysters are consumed locally after thorough cooking. However, the recent trend in consumption of live oysters (Mohamed and Kripa, 2013) makes depuration of shellfish a necessity.

\section{Conclusions}

In India, this is the first-ever assessment, which offer an insight on the accumulation of bacteria in farmed oysters in various season and how influencing the environmental parameters. To protect the health of shellfish consumers, local government authorities are advised to draft regulations and make plans for a cleanup of Ashtamudi Lake based on the results of this monitoring survey. The regulations must make it a mandatory requirement for shellfish from polluted sources to be treated and rendered fit before sale or consumption. Because the oyster $C$. madrasensis is of commercial importance, periodic monitoring has to be performed to determine safety levels for its consumption. E. coli levels in the growing area were relatively high during the monsoon season and below the threshold limits during the pre- and postmonsoon seasons. Hence, we strongly recommend depuration and proper cooking of oysters before consumption during the monsoon season. Relaying and depuration are essential to facilitate the live oyster trade. We recommend monitoring of faecal coliforms in shellfish harvesting areas and in oysters to prevent possible disease outbreaks associated with oyster consumption.

\section{Acknowledgements}

This study was funded by the National Agricultural Innovation Project (NAIP) of the World Bank (P. Code 2000035102), which we gratefully acknowledged. The authors are grateful to the Director of the Central Marine Fisheries Research Institute (CMFRI), Kochi, for facilities and encouragement. We thank Dr. Jesus L Romalde, University of Santiago de Compostela, Department of Microbiology and Parasitology, Santiago de Compostela, A Coruña, Spain, for helpful suggestions that improved this manuscript greatly.

\section{References}

Almeida, C., Soares, F., 2012. Microbiological monitoring of bivalves from the Ria Formosa Lagoon (south coast of Portugal): a 20 years of sanitary survey. Mar. Pollut. Bull. 64, 252-262. http://dx.doi.org/10.1016/j.marpolbul.2011.11.025.

Anderson, K.L., Whitlock, J.E., Valerie, J., Harwood, V.J., 2005. Persistence and differential survival of fecal indicator bacteria in subtropical waters and sediments persistence and differential survival of fecal indicator bacteria in subtropical waters and sediments. Appl. Environ. Microbiol. 71, 3041-3048. http://dx.doi.org/10.1128/AEM.71.6.3041.

APHA, 2012. Recommended Procedures for the Examination of Seawater and Shellfish. twentyfirst ed., Washington, DC.

Ashiq, M., Hasnat, M., Pius, J., Sajudeen, P.A., 2012. Studies on the microbiology of Kallada river in Kollam district (Kerala state). Int. J. Plant Anim. Environ. Sci. 2, 202-205.

Brands, D.A., Inman, A.E., Gerba, C.P., Mare, C.J., Billington, S.J., Saif, L.A Levine, J.F., Joens, L.A., Carolina, N., 2005. Prevalence of Salmonella spp. in Oysters in the United States. Appl. Environ. Microbiol. 71, 893-897. http://dx.doi.org/10.1128/AEM.71.2.893.

Burkhardt, W., Watkins, W.D., Rippey, S.R., 1992. Seasonal effects on accumulation of microbial indicator organisms by Mercenaria mercenaria. Appl. Environ. Microbiol. 58, 826-831.

Chandran, A., Hatha, A.A.M., 2003. Survival of Escherichia coli in a tropical estuary. South Pac. J. Nat. Sci. 21, 41-46.

Chinnadurai, S., Mohamed, K.S., Venkatesan, V., Sharma, J., Kripa, V., 2014 Depuration of bacterial populations in the Indian backwater oyster Crassostrea madrasensis (Preston, 1916): Effects on surface and bottom held oysters. J. Shellfish Res. 33, 409-414. http://dx.doi.org/10.2983/035.0330.0200.

Easterbook, T.J., West, P.A., 1987. Comparison of most probable number and pour-plate procedures for isolation and enumeration of sulphite reducing Clostridium spores and group D faecal streptococci from oysters. J. Appl. Bacteriol. 62, 413-419.

European Communities, 2004a. Commission regulation (EC) No 2074/2005 of 5 december 2005 laying down implementing measures for certain products under regulation (EC) No 853/2004 of the European parliament and of the council and for the organisation of official controls under regulatio. Off. J. Eur. Communities L338, 27-59.

European Communities, 2004b. Commision regulation (EC) No 2073/2005 on microbiological criteria for foodstuffs. Off. J. Eur. communities L338, 1-26.

FAO, 2013. FishStat-Universal software for fishery statistical time series.

Fleming, L.E., Broad, K., Clement, a., Dewailly, E., Elmir, S., Knap, a., Pomponi, S.a., Smith, S., Solo Gabriele, H., Walsh, P., 2006. Oceans and human health: Emerging public health risks in the marine environment. Mar. Pollut. Bull. 53, 545-560. http://dx.doi.org/10.1016/j.marpolbul.2006.08.012.

Hassan, F., Geethalakshmi, V., Jeeva, J.C., Babu, M.R., 2013. Combined effect of lime (Citrus aurantitolia) and drying on reducing bacteria of public health significance in edible oyster (Crassostrea madrasensis). J. Food Sci. Technol. 50, 203-207. http://dx.doi.org/10.1007/s13197-011-0550-6.

Hood, M.A., Ness, G.E., Blake, N.J., 1983. Relationship among fecal relationship among Fecal Coliforms, Escherichia coli, and Salmonella spp. in shellfish. Appl. Environ. Microbiol. 45, 122-126.

Jana, H., Maity, C., Das, A., Pati, B.R., Mitra, A., Mondal, K.C., 2013. Investigating the effect of storage temperature and hot-water treatment on the microbial dynamics in edible oyster (Saccostrea cucullata). Int. J. Postharvest Technol. Innov. 3, 382-391. http://dx.doi.org/10.1504/IJPTI.2013.060270.

Kucuksezgin, F., Kacar, A., Kucuksezgin, G., Uluturhan, E., 2010. Monitoring metal contamination levels and fecal pollution in clam (Tapes decussatus) collected from Izmir bay (Turkey). Environ. Monit. Assess. 162, 407-415. http://dx.doi.org/10.1007/s10661-009-0805-0.

Lalitha, K.V., Surendran, P.K., 2004. Bacterial microflora associated with farmed freshwater prawn Macrobrachium rosenbergii (de Man) and the aquaculture environment. Aquacult. Res. 35, 629-635. http://dx.doi.org/10.1111/j.13652109.2004.01039.x.

Lee, C.-Y., Panicker, G., Bej, A.K., 2003. Detection of pathogenic bacteria in shellfish using multiplex PCR followed by covalink ${ }^{\mathrm{TM}} \mathrm{NH}$ microwell plate sandwich hybridization. J. Microbiol. Methods 53, 199-209. http://dx.doi.org/10.1016/S0167-7012(03)00032-0.

Lees, D., 2000. Viruses and bivalve shellfish. Int. J. Food Microbiol. 59, 81-116.

Mohamed, K.S., Kripa, V., 2013. Oyster farming: New hope for increasing mariculture production in India. MPEDA News Lett. 55-57.

Muniain-Mujika, I., Girones, R., Tofiño-Quesada, G., Calvo, M., Lucena, F., 2002. Depuration dynamics of viruses in shellfish. Int. J. Food Microbiol. 77, 125-133.

Obodai, E.A., Nyarko, H.D., Amponsah, S.L., 2010. Effect of depuration on microbial content of mangrove oyster (Crassostr Ea Tulipa) From Benya Lagoon, Ghana. Ethiop. J. Environ. Stud. Manag. 3, 47-53.

Oliveira, J., Cunha, a., Castilho, F., Romalde, J.L.L., Pereira, M.J.J., 2011. Microbial contamination and purification of bivalve shellfish: Crucial aspects in monitoring and future perspectives-a mini-review. Food Control 22, 805-816. http://dx.doi.org/10.1016/j.foodcont.2010.11.032.

Raveendran, O., Gore, P.S., Iyer, T.S.G., Varma, P.R.G., Sankaranarayanan, V.N, 1990 Occurence of enteric bacteria in seawater and mussels along the southwest coast of India. Indian J. Mar. Sci. 19, 282-284.

Sasikumar, G., Krishnamoorthy, M., 2010. Faecal indicators and sanitary water quality of shellfish-harvesting environment: influences of seasonal monsoon and river-runoff. Indian J. Mar. Sci. 39, 434-444.

Sengor, G.F., 2004. The determination of microbial flora, water activity and chemical analyses in smoked, canned mussels (Mytilus galloprovincialis, L.). Turk. J. Vet. Anim. Sci. 28, 793-797. 